\title{
Intravitreal invading cells contribute to vitreal cytokine milieu in proliferative vitreoretinopathy
}

\author{
I A El-Ghrably, Harminder S Dua, Gavin M Orr, David Fischer, Patrick J Tighe
}

\begin{abstract}
Aim-To examine the contribution of infiltrating cells in the local production of cytokines within the vitreous of patients with proliferative vitreoretinopathy (PVR). Methods-The presence of mRNA coding for IL-6, IL-8, IL-1 $\beta$, IL-1 $\alpha$, TNF $\alpha$, IFN $\gamma$, IL-12, and HPRT was investigated in 25 vitreous samples from patients with PVR, 11 vitreous samples from patients with retinal detachment (RD) not complicated by PVR, and 10 vitreous samples from patients with macular hole (MH). A quantitative reverse transcriptase polymerase chain reaction (RT-PCR) using an internal competitor was used to investigate these samples. From these samples, 15 PVR, $8 \mathrm{RD}$, and $8 \mathrm{MH}$ were analysed for the protein levels of the same cytokines using enzyme linked immunosorbent assay (ELISA). Spearman correlation was used to test any association between mRNA and cytokine protein levels, as an indicator of the contribution these cells make to the intravitreal cytokine milieu.
\end{abstract}

Results-A strong correlation was found between mRNA and their respective cytokine levels (protein products) for IL-6, IL-8, IL-1 $\beta$, IL-1 $\alpha$, TNF $\alpha$, IFN $\gamma$ (Spear$\operatorname{man} r=0.83,0.73,0.67,0.91,0.73$, and 0.73 respectively), but not for IL-12. The median levels of IL-6, IL-8, IL-1ß, and IFN $\gamma$ mRNA and their respective cytokines were significantly higher $(p<0.05)$ in patients with PVR than in those with macular hole. There was no statistically significant difference in the median levels of IL-1 $\alpha$ mRNA between PVR and MH but the cytokine IL-1 $\alpha$ was detected at a significantly higher level in PVR compared with MH patients. Between PVR and $R D$ patients, there was no statistically significant difference in mRNA levels for all the investigated cytokines $(p>0.05)$ except for IL-6 where there was a statistical significance $(p=0.038)$. In contrast, the

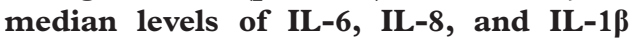
cytokines were significantly higher (p $<0.05$ ) in patients with PVR than in those with RD, whereas for IL-1 $\alpha$ and IFN $\gamma$ no significant statistical difference was detected between PVR and RD patients (p $>0.05$ ). When results of $R D$ and $M H$ patients were compared, a statistical difference was only detected in mRNA levels of INF $\gamma(p=0.008)$. However, no difference was detected for INF $\gamma$ (protein product) or for any of the other cytokines between RD and MH patients.

Conclusion-Levels of both protein and mRNA encoding IL-6, IL-8, IL-1 $\beta$, and IFN $\gamma$ is significantly increased in vitreous samples from patients with PVR. The strong correlation between ELISA detectable cytokines (protein products) and their respective mRNA levels suggest that intravitreal, invasive cells are the major source of these cytokines, with the exception of IL-12. Cells invading the vitreous do not appear to locally produce IL-12 mRNA. This would appear to implicate cells peripheral to the vitreal mass as the major source of this cytokine.

(Br f Ophthalmol 2001;85:461-470)

Proliferative vitreoretinopathy (PVR) is still the most common cause of failure of surgery for rhegmatogenous retinal detachment (RRD) despite the substantial effort that has been devoted to better understanding and management of this condition during the past 25 years. ${ }^{12}$ It is characterised by the formation of membranes extending along both surfaces of the detached retina and within the vitreous. $^{3}$

The PVR process can be considered as a modified wound healing process, which is initiated by injury (retinal break) that causes a retinal detachment. The most important factor is probably the excessive inflammatory reaction that occurs in some clinical situations that predispose to PVR. The exact pathogenic mechanisms involved in the formation of PVR are not completely understood. However, five distinct stages appear to be important in its development including breakdown of the blood-retinal barrier (BRB), chemotaxis, and cellular migration, cellular proliferation, membrane formation with remodelling of the extracellular matrix, and contraction. ${ }^{4-6}$

Cytokines are polypeptides produced principally by activated inflammatory and immune cells that regulate immune response and inflammatory reactions. ${ }^{7}$ They act as chemical mediators between different cell types and, either by themselves or by interacting with each other, the cytokine networks may mediate cellular mechanisms of migration, proliferation, and differentiation, which are involved in PVR membrane formation. ${ }^{8}$ Interleukin 1 (IL-1) and IL-6 are functionally related cytokines that have broad spectrum of activity in inflammation and wound healing. In wound healing, IL-6 stimulates the proliferation of fibroblast and glial cells and the synthesis of 
Table 1 Primer sequences, deletion, and target information: all PCR targets and deletion sites are given as nucleotide positions from the cited Genbank sequence. The a primer in each case was synthesised with a 5' fluorophore attached (fluorophores are those marketed by ABI Applied Biosystems Ltd)

\begin{tabular}{|c|c|c|c|c|c|}
\hline Target & Accession No & PCR product & Deletion site & Primer sequence (5'-3') & Fluorophore \\
\hline HPRT & M31642 & $407-566$ & $537-541$ & $\begin{array}{l}\text { (a) GACCAGTCAACAGGGGACAT } \\
\text { (b) CGACCTTGACCATCTTTGGA }\end{array}$ & Hex \\
\hline $\mathrm{IL}-1 \alpha$ & M28983 & $496-670$ & $521-525$ & $\begin{array}{l}\text { (a) GCTGCTGCATTACATAATCTGG } \\
\text { (b) TGGGTATCTCAGGCATCTCC }\end{array}$ & Fam \\
\hline IL-1 $\beta$ & M15330 & $83-182$ & $153-157$ & $\begin{array}{l}\text { (a) AGCCATGGCAGAAGTACCTG } \\
\text { (b) CATCTGTTTAGGGCCATCAG }\end{array}$ & Hex \\
\hline IL-6 & M14584 & $188-332$ & $212-216$ & $\begin{array}{l}\text { (a) AGGTTGTTTTCTGCCAGTGC } \\
\text { (b) CACACAGACAGCCACTCACC }\end{array}$ & Fam \\
\hline IL-8 & M26383 & $36-253$ & $222-226$ & $\begin{array}{l}\text { (a) AAGAAACCACCGGAAGGAAC } \\
\text { (b) TGTGGTCCACTCTCAATCACTC }\end{array}$ & Fam \\
\hline IL-12 & M65272 & $835-963$ & $862-866$ & $\begin{array}{l}\text { (a) CCACATTCCTACTTCTCCCTGA } \\
\text { (b) GCTAATGCTGGCATTTTTGC }\end{array}$ & Tet \\
\hline $\mathrm{TNF} \alpha$ & X01394 & $284-512$ & $306-310$ & $\begin{array}{l}\text { (a) CACCACGCTCTTCTGCCT } \\
\text { (b) TCTCAGCTCCACGCCATT }\end{array}$ & Fam \\
\hline $\mathrm{IFN} \gamma$ & M29383 & $501-642$ & $524-528$ & $\begin{array}{l}\text { (a) TGACTTGAATGTCCAACGCAAAG } \\
\text { (b) GCAGGACAACCATTACTGGGATG }\end{array}$ & Tet \\
\hline
\end{tabular}

collagen, ${ }^{9}$ whereas IL-1 stimulates the migration of retinal pigment epithelial (RPE) cells. ${ }^{10}$

Tumour necrosis factor alpha $(\mathrm{TNF} \alpha)$ is known to be chemotactic for monocytes and fibroblasts, ${ }^{11}$ and it acts synergistically with interferon gamma (IFN $\gamma$ ) and IL-1 in the induction of ICAM-1 by RPE cells. This may contribute to the immunopathological processes in this disease. ${ }^{12}$

Macrophages, monocytes, $\mathrm{T}$ lymphocytes, neutrophils, RPE cells, and glial cells are found in the vitreous of patients with PVR. ${ }^{13-16}$ In RD the presence of these cellular components is variable and the vitreous in $\mathrm{MH}$ patients is largely devoid of inflammatory cells. Neutrophils and monocytes, which play an important part in PVR development, ${ }^{13}$ are attracted to inflammatory sites by chemokines such as IL-8. Most cellular components of PVR membranes, including the RPE cells and macrophages, are capable of secreting these cytokines. $^{14-16}$

Many studies have been conducted to ascertain the expression of the various cytokines in the vitreous and PVR membranes and their relation to the development of PVR. ${ }^{17-24}$ These studies have examined either the proteins present within the vitreous, or a limited number of cytokine mRNAs from intravitreal cells, but not both together. Thus, while the proteins have been shown to be present and the potential of cells to express some cytokine mRNAs locally has been reported, there has been no correlation between cytokine levels within the vitreous and the potential for production by the invasive cells. This is essential to establish the impact of cytokine production by the invasive cells on the overall environment.

In previous work from this laboratory ${ }^{25}$ we reported the detection of IL1 $\beta$, IL6, IL8, and $\mathrm{TNF} \alpha$ mRNA in vitreous samples from patients with PVR, RD, and $\mathrm{MH}$; however, the methodology used was not quantitative and thus the significance of the production of mRNA in relation to the secreted proteins could not be determined.

In this study we have significantly expanded our investigations by using quantitative techniques for both mRNA and protein detection, and have expanded the range of studied cytokines to include IFN $\gamma$, IL $1 \alpha$, and IL12 as well as those previously mentioned. To our knowledge this is the first quantitative measurement of both mRNA and protein expression in these conditions. This has allowed us to correlate mRNA and secreted cytokine protein levels to determine whether the cells invading the vitreous play a major part in the production of the detected cytokine milieu. In addition, we have addressed, for the first time, the contribution of IL-12 in the pathogenesis of PVR.

\section{Materials and methods}

PATIENTS

A total of 46 consecutive patients (25 with PVR, 11 with RD not complicated by PVR, and 10 patients with macular hole $(\mathrm{MH}))$ in whom vitrectomy was considered necessary, were investigated in the ophthalmology department, QMC, Nottingham, UK. Of the 46 patients, 31 were men and 15 were women. The mean age was 49 years (range 30-87 years). Indications for vitrectomy in eyes with $\mathrm{RD}$ were failure of retinal reattachment by conventional methods (buckling and cryo), giant breaks, very posterior breaks, and multiple breaks not suitable for buckle. Patients with a history of recent trauma (3 months), concurrent eye conditions such as infection, vitreous haemorrhage or uveitis, and current topical or systemic steroids were excluded. The severity of PVR was graded according to the criteria of Retina Society Terminology committee. ${ }^{1}$ The same observer followed up patients for a period ranging between 4 and 18 months (average 9 months). Data concerning the number of surgeries before PVR development, duration of retinal disease, and severity and recurrence of PVR were documented for the purpose of this study. Patients admitted into the study gave their informed consent and the study complied with the Declaration of Helsinki.

VITREOUS SPECIMENS

Samples were obtained through the conventional three port closed vitrectomy technique. They were collected undiluted by manual suction into a syringe through the aspiration line 

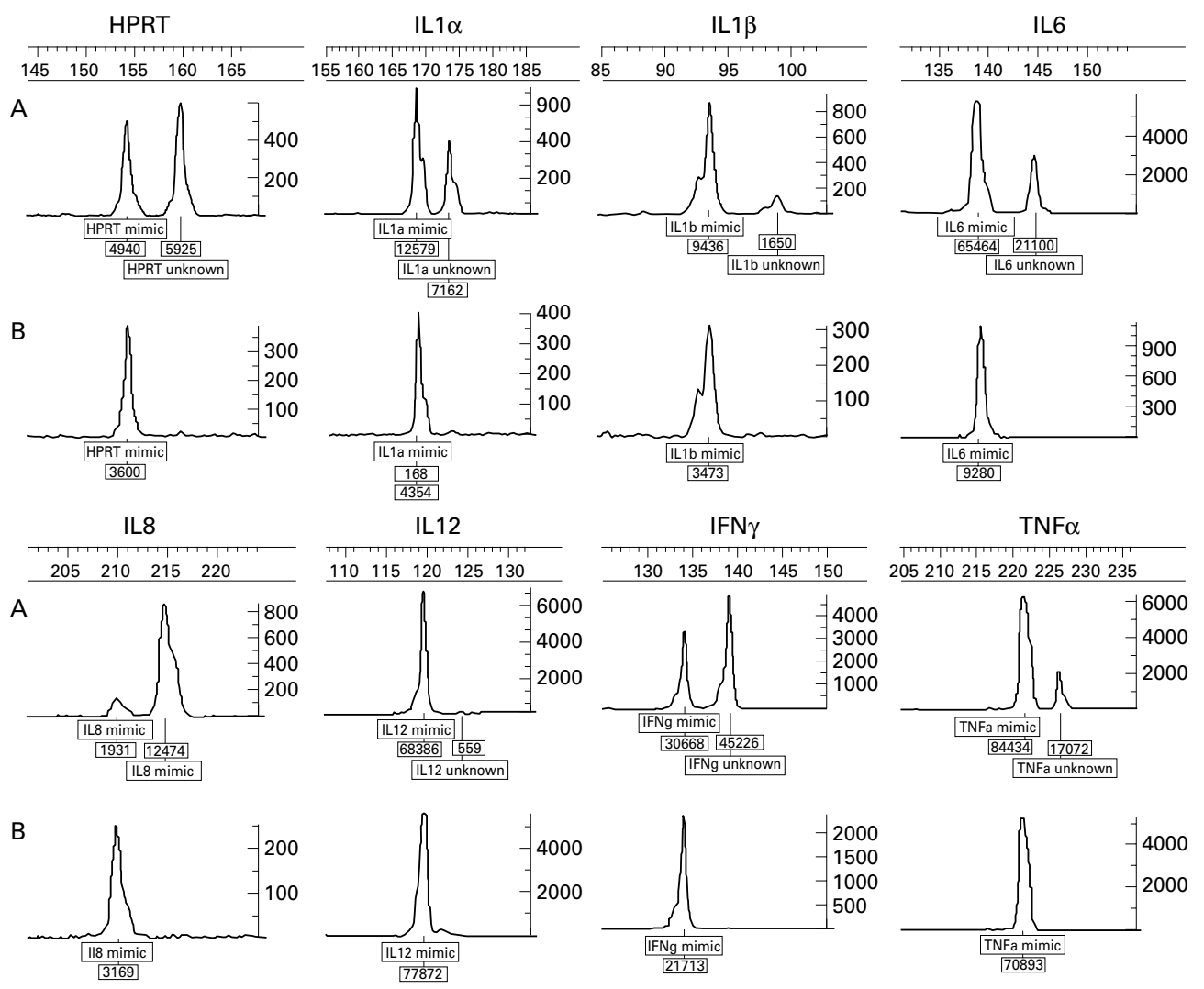

Figure 1 A typical electropherogram plot showing the size and area peaks for mimic and unknown (sample) of investigated cytokines. (A) Positive samples, (B) negative samples. Unknown concentration = (area of unknown/area of mimic) $\times$ mimic concentration.

of vitrectome before opening the infusion line. Intraocular pressure was maintained by indentation. When a sample of approximately $0.75-1 \mathrm{ml}$ was obtained the ocutome was withdrawn and infusion commenced to restore ocular volume. Samples were then transferred to $1.8 \mathrm{ml}$ polypropylene tubes and prepared immediately following surgery. Cells were pelleted by centrifugation at $2500 \mathrm{rpm}$ for 10-15 minutes. Supernatants were divided into aliquots and stored at $-70^{\circ} \mathrm{C}$ until used for enzyme linked immunosorbent assays (ELISA). Cellular pellets were processed rapidly to prevent RNA degradation. Total RNA was extracted using the RNeasy method (Qiagen, UK) following manufacturer's procedure. RNA was stored at $-70^{\circ} \mathrm{C}$ until cDNA synthesis and PCR reaction were carried out. cDNA was prepared from all the RNA extracted from each sample using oligo-(dT) priming in ready to go cDNA synthesis tubes (Pharmacia Biotech, UK) following the manufacturer's procedure.

\section{QUANTITATIVE RT-PCR REACTIONS}

Primers

Primer pairs, one of which was fluorescent dye labelled, were synthesised by MWG Biotech (MWG, Germany). All primer pairs were validated by sequencing of PCR products generated under the conditions stated. For primer sequences see Table 1 .

To correct for variation in amplification efficiency between individual reactions, target
cDNA was co-amplified with an internal competitor (mimic) of known concentration using the same fluorescent labelled primers. Quantitative PCR was performed using a variation of the method of Pannetier, ${ }^{26}$ which provides quantitative data even when the PCR is cycled into saturation. This is only possible if the competitor sequence is essentially identical to the true target sequence. ${ }^{27}$ Highly homologous competitor DNA (mimics) were generated by PCR mutagenesis of the true PCR products for each target sequence. Five base pair deletions were produced in each mimic, 25 bases from the $5^{\prime}$ end of either the $a$ or $b$ primer site (depending on most suitable primer design). The location of the PCR targets and deletions are given in Table 1 . This method gives mimics which, when co-amplified with cDNA, remain proportional across the detectable range of fluorescent detection (approximately 4 logs) (data not shown).The mimic PCR products were cloned into pT7 blue (Novagen, UK) and verified by sequencing.

PCR amplification was performed by adding $1 \mu \mathrm{l}$ of each cDNA sample to a final reaction mixture of $25 \mu \mathrm{l}$ containing $60 \mathrm{mM}$ TRIS.Cl (pH 8.0), $15 \mathrm{mM}\left(\mathrm{NH}_{4}\right)_{2} \mathrm{SO}_{4}, 2 \mathrm{mM} \mathrm{Mg} \mathrm{Cl}$, $0.2 \mathrm{mM}$ each dNTP, $0.01 \%$ Tween $20,0.5$ units Amplitaq Gold (Perkin Elmer, Warrington, UK), $0.2 \mu \mathrm{M}$ each primer; $10^{3}$ single strands per reaction of appropriate mimic was added. In negative controls no sample was added to the reaction mix although mimic was still included. Amplification cycles (performed 

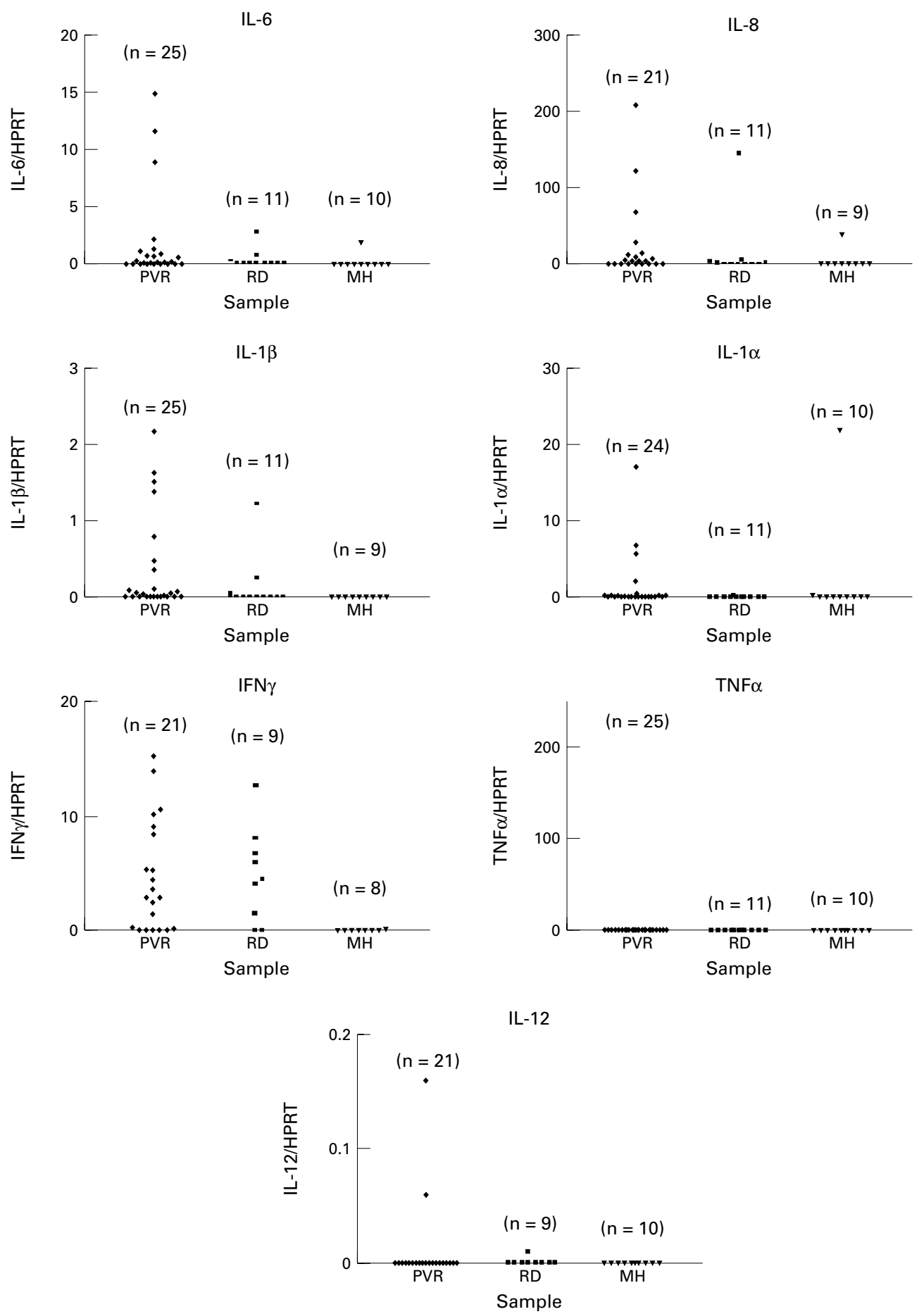

Figure $2 m R N A$ levels of different cytokines normalised to HPRT in vitreous aspirates obtained from patients with proliferative vitreoretinopathy (PVR), retinal detachment (RD), and macular hole (MH) (control). $n=$ number of investigated samples.

on a Progene instrument from Techne, UK) were; $94^{\circ} \mathrm{C}, 10$ minutes, then 37 cycles of $94^{\circ} \mathrm{C}, 1$ minute; $54^{\circ} \mathrm{C}, 1$ minute; $72^{\circ} \mathrm{C}$, 1 minute 30 seconds; followed by $72^{\circ} \mathrm{C}$ for 15 minutes. Fluorophore labelled PCR products $(0.5 \mu \mathrm{l})$ were separated and analysed by capillary electrophoresis under denaturing conditions (POP4 polymer) on a Prism310 genetic analyser, (Applied Biosystems). Run conditions were 5 seconds injection, $15 \mathrm{kV}$, run
24 minutes at $15 \mathrm{kV}, 60^{\circ} \mathrm{C}, 36 \mathrm{~cm}$ capillary (length to detection). Size and area of DNA peaks were obtained using standard software (Genescan version 2.0 and Genotyper v1.1.1. Perkin Elmer ABI). The amount of each cytokine mRNA in the samples was calibrated by the known concentration of mimic using the following formula:

Unknown concentration = (area of unknown/ area of mimic) $\times$ mimic concentration 
Table 2 Cytokine $m R N A$ levels normalised to HPRT in vitreous samples with summary of statistical data analysis

\begin{tabular}{|c|c|c|c|c|c|c|}
\hline \multirow[b]{2}{*}{ Cytokine $m R N A$} & \multirow[b]{2}{*}{ No } & \multirow[b]{2}{*}{$N(\%)$} & \multirow[b]{2}{*}{ Median } & \multirow[b]{2}{*}{$I Q R$} & \multicolumn{2}{|l|}{$p$ Value } \\
\hline & & & & & $v M H$ & $v R D$ \\
\hline \multicolumn{7}{|l|}{ PVR: } \\
\hline IL-6/HPRT & 25 & $19(76)$ & 0.16 & $0.02-1.03$ & 0.005 & 0.038 \\
\hline IL-8/HPRT & 25 & $23(92)$ & 4.43 & $0.81-13.87$ & 0.006 & 0.081 \\
\hline IL-1 $\beta /$ HPRT & 25 & $16(64)$ & 0.04 & $0.0-0.42$ & 0.004 & 0.086 \\
\hline TNF $\alpha / H P R T$ & 25 & $5(20)$ & 0.0 & $0.0-0.0$ & $\dagger$ & $\dagger$ \\
\hline IL- $1 \alpha /$ HPRT & 25 & $14(56)$ & 0.03 & $0.0-0.24$ & 0.200 & 0.072 \\
\hline IFN $\gamma / \mathrm{HPRT}$ & 21 & $18(85)$ & 2.91 & $0.10-8.79$ & $<0.001$ & 0.838 \\
\hline IL-12/HPRT & 21 & $2(10)$ & 0.0 & $0.0-0.0$ & $\dagger$ & $\dagger$ \\
\hline RD: & & & & & $v M H$ & \\
\hline IL-6/HPRT & 11 & $3(27)$ & 0.0 & $0.0-0.50$ & 0.531 & \\
\hline IL-8/HPRT & 11 & $7(64)$ & 0.35 & $0.0-4.82$ & 0.143 & \\
\hline IL- $1 \beta /$ HPRT & 11 & $3(27)$ & 0.0 & $0.0-0.13$ & 0.331 & \\
\hline TNF $\alpha / H P R T$ & 11 & $0(0)$ & 0.0 & $0.0-0.0$ & $\dagger$ & \\
\hline IL-1 $\alpha /$ HPRT & 11 & $2(18)$ & 0.0 & $0.0-0.02$ & 0.912 & \\
\hline IFN $\gamma / \mathrm{HPRT}$ & 9 & $7(78)$ & 4.4 & $0.75-7.37$ & 0.008 & \\
\hline IL-12/HPRT & 9 & $1(11)$ & 0.0 & $0.0-0.0$ & $t$ & \\
\hline \multicolumn{7}{|l|}{ MH: } \\
\hline IL-6/HPRT & 10 & $1(10)$ & 0.0 & $0.0-0.0$ & & \\
\hline IL-8/HPRT & 10 & $3(30)$ & 0.0 & $0.0-0.570$ & & \\
\hline IL-1ß/HPRT & 10 & $1(10)$ & 0.0 & $0.0-0.0$ & & \\
\hline $\mathrm{TNF} \alpha / \mathrm{HPRT}$ & 10 & $0(0)$ & 0.0 & $0.0-0.0$ & & \\
\hline IL- $1 \alpha /$ HPRT & 10 & $2(20)$ & 0.0 & $0.0-0.12$ & & \\
\hline IFN $\gamma /$ HPRT & 10 & $3(30)$ & 0.0 & $0.0-0.0$ & & \\
\hline IL-12/HPRT & 10 & $0(0)$ & 0.0 & $0.0-0.0$ & & \\
\hline
\end{tabular}

No = number of samples examined; $\mathrm{N}=$ number of positive samples; IQR $=$ interquartile range ${ }^{\star}$ Significant difference $\mathrm{p}<0.05$ between the two groups (Mann-Whitney).

†No statistical difference was found between groups (Kruskal-Wallis).

HPRT (hypoxanthine phosphoribosyl transferase), a constitutively expressed housekeeping gene was used to normalise the amount of mRNA present in each sample. Peak detection by the analysis software is set to detect appropriately shaped peaks, in the designated size range for each PCR product, with a height of more than 30 arbitrary fluorescence units (AFU) over baseline. Baseline fluorescence for the detection system is, on average, $20 \mathrm{AFU}$, with some digital noise from the CCD, which is automatically filtered out. Typical electropherogram plots showing the size and area of peaks for mimic and unknown are shown in Figure 1.

Enzyme linked immunosorbent assays (ELISA) From previously examined vitreous samples, 15 PVR, eight RD, and eight $\mathrm{MH}$ were examined for their levels of IL-6, IL-8, IL-1 $\beta$, IL- $1 \alpha$, $\mathrm{TNF} \alpha$, IFN $\gamma$, and IL-12 using sandwich enzyme immunoassay kits (R\&D systems, Oxon, UK). Different types of kits were used according to sensitivity and expected levels of different cytokines. A calibration run was made on a few vitreous samples before each assay, to determine the appropriate sample dilution. A dilution of $1: 3$ was found to be appropriate for all cytokines with the exception of IL- $1 \beta$ where a dilution of 1:2 was used. These preliminary assays ensured that the levels of factors in the samples were within the detectable range of the assay kits.

The vitreous sample volumes used were 150 $\mu \mathrm{l}$ for IL-6, IL-8, and IL-1 $\beta$ and $200 \mu \mathrm{l}$ for $\mathrm{TNF} \alpha$, IL- $1 \alpha, \mathrm{IFN} \gamma$, and IL-12. Sonication (on ice) was performed to completely disrupt formed vitreous and yield homogeneous sample for assay and prevent loss of antigenic activity. All samples were examined in duplicates and the average reading was analysed.
The minimum detectable concentrations (sensitivity) for the assay kits were $0.3,1.6,0.125$, $3.9,0.7,15.6$, and $0.7 \mathrm{pg} / \mathrm{ml}$ for IL-6, IL-8, IL- $1 \beta$, IL- $1 \alpha, \mathrm{TNF} \alpha$, IFN $\gamma$, and IL- 12 respectively. Elisa assays were carried out according to the manufacturer's instructions.

STATISTICAL ANALYSIS

Non-parametric tests were used for statistical analysis of our data, which is not normally distributed. Samples were divided into three groups-PVR, RD, and MH. Vitreous cytokine levels between groups were analysed using the Kruskal-Wallis test, and the levels between two groups were compared using a MannWhitney test. The Spearman correlation test was used to test any association between mRNA and cytokine protein levels. Groups in different clinical variables were compared using Kruskal-Wallis and Mann-Whitney tests whenever appropriate. Statistical calculations were performed using commercial software (Prism version 2.01).

\section{Results}

CYTOKINE mRNA

mRNA levels of different cytokines in vitreous samples from patients with PVR, RD, and $\mathrm{MH}$ were normalised to the level of HPRT mRNA detected in the sample. The HPRT mRNA level would reflect the cellularity of the sample. Uniformly low levels of HPRT were detected indicating the low number of cells present in the vitrectomy samples. By normalising the cytokine mRNA against HPRT mRNA for each sample, spurious differences in cytokine mRNA levels between samples, were avoided. These results are shown in Figure 2.

The median levels of IL-6, IL-8, IL- $1 \beta$, and IFN $\gamma$ mRNA were significantly higher ( $p$ $<0.05$ ) in patients with PVR than those with macular hole. There was no statistically significant difference between the median levels of the two groups for IL- $1 \alpha$.

Comparing PVR with RD patients, there was no statistically significant difference in mRNA levels between the two groups in all the investigated cytokines ( $p>0.05$ ) except for IL-6 where, there was statistical significance $(p=0.038)$. The median level of IFN $\gamma$ mRNA was significantly higher $(p=0.008)$ in patients with $\mathrm{RD}$ than those with $\mathrm{MH}$, otherwise there was no significant difference between the two groups.

There were very few samples with detectable mRNA levels for TNF $\alpha$ and IL-12, (no significant difference between groups was found by Kruskal-Wallis test). Number and percentage of samples with detectable levels of mRNA for different cytokines and the results of statistical analysis between different groups are summarised in Table 2.

CYTOKINE PROTEIN ASSAY

Levels of different cytokines in vitreous samples from patients with PVR, RD, and $\mathrm{MH}$ expressed in $\mathrm{pg} / \mathrm{ml}$ are shown in Figure 3. A summary of the available data and statistical analysis is shown in Table 3. The median levels 

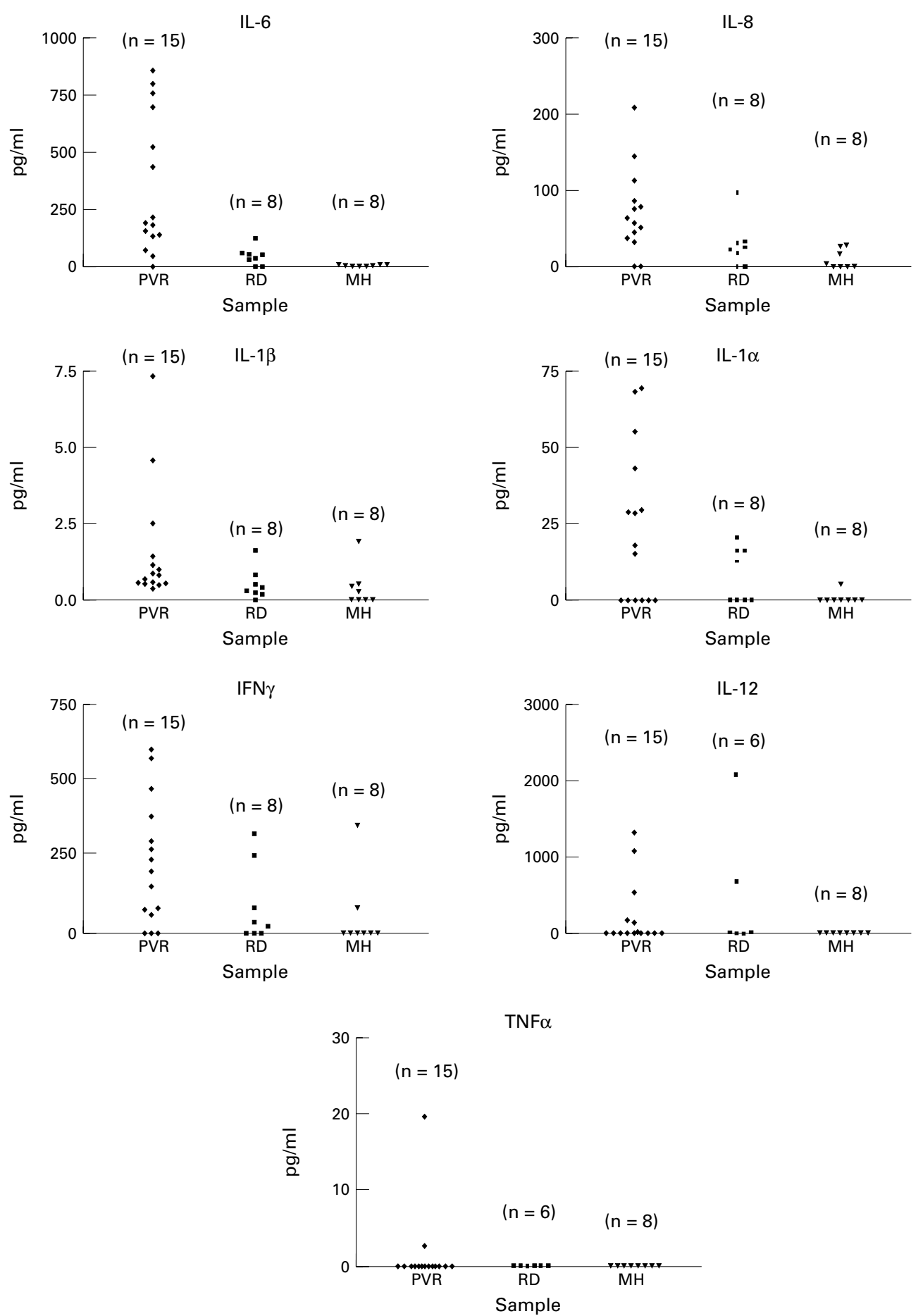

Figure 3 Levels of different cytokines in vitreous aspirates obtained from patients with proliferative vitreoretinopathy $(P V R)$, retinal detachment $(R D)$, and macular hole $(M H)$ (control). $n=$ number of investigated samples. Detection levels were $(0.3,1.6,0.125,3.9,0.7,15.6$, and $0.7 \mathrm{pg} / \mathrm{ml}$ for $I L-6, I L-8, I L-1 \beta, I L-1 \alpha, T N F a, I F N \gamma$, and IL-12 respectively.

of IL-6, IL-8, and IL-1 $\beta$ were significantly higher $(\mathrm{p}<0.05)$ in patients with PVR than those with $\mathrm{MH}$ and RD. For IL- $1 \alpha$ and IFN $\gamma$, a significant statistical difference was detected between PVR and MH groups $(p<0.05)$ but not between PVR and RD patients ( $p>0.05)$. No significant difference was found between $\mathrm{RD}$ and $\mathrm{MH}$ groups in all the tested cytokines. According to Kruskal-Wallis test no significant difference between groups was found for TNF $\alpha$ and IL-12 ( $\mathrm{p}>0.05)$.
CORRELATION BETWEEN MRNA AND CYTOKINE PROTEIN LEVELS

A total of 31 pairs of samples were analysed (29 for IFN $\gamma$ and IL-12) for their mRNA and protein correlation levels. Statistically significant correlation was found between mRNA and cytokine levels for IL-6, IL-8, IL-1 $\beta$, IL- $1 \alpha, \mathrm{TNF} \alpha$, IFN $\gamma$, Spearman $r=0.83,0.73$, $0.67,0.91,0.73$, and 0.73 respectively. No significant correlation was found between mRNA and cytokine levels for IL-12 $(r=0.18)$. 
Table 3 Cytokine levels expressed in $\mathrm{pg} / \mathrm{ml}$ in vitreous samples with summary of statistical data analysis

\begin{tabular}{|c|c|c|c|c|c|c|}
\hline \multirow[b]{2}{*}{ Cytokine } & \multicolumn{3}{|c|}{ Positive } & \multirow[b]{2}{*}{$I Q R$} & \multicolumn{2}{|c|}{ p Value ${ }^{*}$} \\
\hline & No & $N(\%)$ & Median & & $v M H$ & $v R D$ \\
\hline \multicolumn{7}{|l|}{ PVR: } \\
\hline IL-6 & 15 & $14(93)$ & 190.6 & $136.4-725.6$ & $<0.001$ & 0.002 \\
\hline IL-8 & 15 & $13(86)$ & 63.56 & $41.37-128.6$ & 0.003 & 0.018 \\
\hline IL-1 $\beta$ & 15 & $15(100)$ & 0.82 & $0.57-1.99$ & 0.004 & 0.014 \\
\hline IL-1 $\alpha$ & 15 & $9(60)$ & 18.1 & ND-49.60 & 0.033 & 0.205 \\
\hline $\mathrm{TNF} \alpha$ & 15 & $2(13)$ & ND & ND & + & $t$ \\
\hline $\mathrm{IFN} \gamma$ & 15 & $12(80)$ & 200.8 & $68.37-426.3$ & 0.030 & 0.129 \\
\hline IL-12 & 15 & $10(67)$ & 1.457 & ND-349.8 & $\dagger$ & + \\
\hline RD: & & & & & v MH & \\
\hline IL-6 & 8 & $6(75)$ & 42 & $14-50.92$ & 0.065 & \\
\hline IL-8 & 8 & $6(75)$ & 22.93 & $9.08-30.95$ & 0.195 & \\
\hline IL-1 $\beta$ & 8 & $7(88)$ & 0.34 & $0.22-0.66$ & 0.382 & \\
\hline $\mathrm{IL}-1 \alpha$ & 8 & $4(50)$ & 6.25 & ND-16.05 & 0.160 & \\
\hline $\mathrm{TNF} \alpha$ & 6 & $0(0)$ & ND & ND & + & \\
\hline $\mathrm{IFN} \gamma$ & 8 & $5(63)$ & 27.15 & ND-165.4 & 0.382 & \\
\hline IL-12 & 6 & $4(67)$ & 14.51 & ND - 1365 & + & \\
\hline \multicolumn{7}{|l|}{ MH: } \\
\hline IL-6 & 8 & $6(75)$ & 4.34 & $0.83-7.05$ & & \\
\hline IL-8 & 8 & $5(63)$ & 2.50 & ND-22.35 & & \\
\hline IL-1 $\beta$ & 8 & $4(50)$ & 0.14 & ND-0.49 & & \\
\hline IL-1 $\alpha$ & 8 & $1(13)$ & ND & ND & & \\
\hline $\mathrm{TNF} \alpha$ & 8 & $0(0)$ & ND & ND & & \\
\hline IFN $\gamma$ & 8 & $2(25)$ & ND & ND-40.22 & & \\
\hline IL-12 & 8 & $3(38)$ & ND & ND- 0.87 & & \\
\hline
\end{tabular}

No = number of samples examined; $\mathrm{N}=$ number of positive samples; IQR = interquartile range; $\mathrm{ND}=$ below detection level $(0.3,1.6,0.125,3.9,0.7,15.6$, and $0.7 \mathrm{pg} / \mathrm{ml}$ for IL-6, IL-8, IL-1 $\beta$, IL- $1 \alpha, \mathrm{TNF} \alpha, \mathrm{IFN} \gamma$, and IL-12 respectively.

${ }^{\star}$ Significant difference $\mathrm{p}<0.05$ between the two groups. (Mann-Whitney)

$\dagger$ No statistical difference was found between groups (Kruskal-Wallis).

mRNA LEVELS AND RELATION TO CLINICAL DATA Table 4 shows summary of clinical variables investigated and their relation to mRNA levels for different cytokines. No significant difference was found between different clinical groups in their mRNA cytokine levels ( $p$ $>0.05)$.

\section{Discussion}

The precise role of individual cytokines in the pathogenesis of PVR is not obviously clear, but their involvement in regulating immune and inflammatory responses has been well described.

mRNA quantitation can provide information on gene expression and its control, and help in understanding the regulatory systems governing it and the physiological role it performs. ${ }^{28}$ However, mRNA level is a reflection of gene expression and not protein production, and there is not always a correlation between mRNA and secreted protein levels and this depends upon the regulatory mechanisms for any particular expressed gene.
By studying both mRNA and secreted protein the usefulness of RT-PCR assays was substantially enhanced. The good correlation demonstrated between mRNA and the respective cytokines suggests that, in PVR, mRNA estimation can be an indicator of the respective cytokines secreted. Competitive polymerase chain reaction (PCR) is considered the method of choice for gene expression studies in small clinical samples. The accurate quantitation of PCR products relies on the use of an internal standard, which is designed to contain primer binding and flanking sequences identical to the target gene fragment. ${ }^{29}{ }^{30}$ In this study the internal standard (mimic) was sufficiently different in size from the target gene fragment (five bases shorter) for unambiguous detection, but is close enough in size to ensure minimal differences in amplification efficiency. The final ratio of amplified target to the amplified competitor is dependent on the initial ratio of the target to the competitor, rendering the reaction independent of the number of amplification cycles. ${ }^{30}$ Previous work to detect mRNA coding for IL-6, IL-1 $\beta$, and $\mathrm{TNF} \alpha$ in epiretinal membranes from patients with PVR was carried out by Limb et al in $1994 .^{31}$ They used an in situ hybridisation technique which, although sensitive, is technically very demanding for obtaining data on quantitation. We recently reported the use of RT-PCR technique to detect mRNA for IL-6, IL-1 $\beta$, IL-8, and TNF $\alpha$ in vitreous samples from patients with PVR. ${ }^{25}$ However, no data on the measurement of the protein product (cytokines), in the samples studied, were presented.

Unlike other inflammatory conditions such as coeliac disease, ${ }^{32}$ and rheumatoid arthritis, ${ }^{33}$ in which large amounts of cytokine mRNAs may be expressed in the heavily infiltrated affected tissues, the present results showed that vitreous samples in PVR possessed relatively little cytokine mRNA reflecting the relatively lower number of cells. Although direct estimation of total mRNA in each sample was not carried out, the levels of HPRT mRNA detected were low, indicating that the overall cellularity of the vitreous samples was low. In our study, there was a general trend towards higher levels of IL-6, IL-8, IL-1 $\beta$, and IFN $\gamma$ mRNA in retinal detachment (whether or not complicated by PVR) than $\mathrm{MH}$

Table 4 Relation between clinical variables and cytokine $m R N A$ level normalised to HPRT

\begin{tabular}{|c|c|c|c|c|c|c|c|}
\hline \multirow[b]{2}{*}{ Clinical variable } & & \multirow[b]{2}{*}{ No } & \multicolumn{5}{|c|}{ Number of patients with detectable cytokine mRNA levels (\%) } \\
\hline & & & $I L-6 / H P R T$ & $I L-8 / H P R T$ & $I L-1 \beta / H P R T$ & $I F N \gamma / H P R T \neq^{\star}$ & $I L-1 a / H P R T$ \\
\hline \multirow[t]{2}{*}{ Severity } & $\mathrm{C} 1-\mathrm{C} 2$ & 19 & $13(68)$ & $17(89)$ & $12(63)$ & $14(87)$ & $10(52)$ \\
\hline & C3-D2 & 6 & $6(100)$ & $6(100)$ & $4(66)$ & $4(80)$ & $4(66)$ \\
\hline \multirow[t]{3}{*}{ Duration } & $2-8$ weeks & 14 & $10(71)$ & $14(100)$ & $8(57)$ & $11(84)$ & $9(64)$ \\
\hline & $8-14$ weeks & 5 & $4(80)$ & $4(80)$ & $3(60)$ & $3(75)$ & $3(60)$ \\
\hline & $>14$ weeks & 6 & $5(83)$ & $5(83)$ & $5(83)$ & $4(100)$ & $2(33)$ \\
\hline \multirow[t]{2}{*}{ Recurrence } & No & 14 & $9(64)$ & $12(86)$ & $7(50)$ & $10(83)$ & $6(43)$ \\
\hline & Yes & 11 & $10(91)$ & $11(100)$ & $9(82)$ & $8(89)$ & $8(72)$ \\
\hline \multirow[t]{3}{*}{ No of previous surgeries } & 0 & 7 & $5(71)$ & $6(86)$ & $4(57)$ & $5(100)$ & $3(43)$ \\
\hline & 1 & 11 & $7(63)$ & $10(91)$ & $6(54)$ & $8(80)$ & $6(55)$ \\
\hline & $2-4$ & 7 & $7(100)$ & $7(100)$ & $6(86)$ & $5(83)$ & $5(71)$ \\
\hline
\end{tabular}

No $=$ number of samples examined.

${ }^{\star}$ Number of samples investigated in each clinical group was slightly less than the examined number for other cytokines, due to insufficient sample. 
samples. However, statistically significant higher levels were found only in PVR samples. Similarly, cytokine protein levels were significantly higher for IL-6, IL-8, IL-1 $\beta$ in PVR than RD and MH. Apart from IL-12, a significant correlation was found $(r>0.4)$ between mRNA and protein levels in all the investigated cytokines. The substantial variation in values within each group of patients, and the number of samples available limit the conclusions that can be drawn from this initial study.

The presence of cytokine protein without detection of its mRNA was apparent in some samples (eight samples for IL-6, seven for IL-8, 10 for IL-1 $\beta$, one for IL- $1 \alpha$, and two for IFN $\gamma$ ). Since translation of $m R N A$ occurs rapidly, this observation does not preclude that these cytokines are produced within the ocular microenvironment. Cytokines may also be produced outside the vitreal microenvironment and permeate the vitreous during breakdown of the blood retinal barrier. Alternatively, cytokines may be expressed by the retina, which is known to be a source of many cytokines and growth factors. ${ }^{34}$ Retinal tissue is a potential contaminant for vitreous samples and dissected epiretinal membranes. Scleral wounds created during vitreoretinal surgery can act as an important source for growth factors and cytokines. ${ }^{34}$

In contrast, several samples were found to have mRNA for a cytokine in the absence of detectable protein (four samples for IL-8, one for IL- $1 \beta$, four for IL- $1 \alpha$, three for $\mathrm{TNF} \alpha$, and four for IFN $\gamma$ ). Cytokine proteins may be present below the detection levels of the ELISA kits used. Another possibility is that some of these cytokines are bound to extracellular matrix in epiretinal membranes and not present free in the vitreous (as has been previously shown for $\mathrm{TNF} \alpha$ for example). ${ }^{18}$ In addition, regulation of secretion of these cytokines at translational and post translational levels may occur.

It was not possible to identify any relation between cytokine mRNA levels and different clinical groups, perhaps because of the small number of samples available in each group. In a recent study, ${ }^{24}$ in which large numbers of patients were investigated for fewer cytokines by ELISA, IL-6 levels in vitreous were found to be predictive for the development of postoperative PVR. The presence of these cytokines in some macular hole and retinal detachment vitreous samples suggests that any role that these cytokines have in promoting the development of the epiretinal membranes might result from an altered balance in their activities, difference in their microdistribution, or change in receptor expression or activity rather than the absolute presence or absence of the factor.

In the present study, the types of cells expressing each cytokine were not identified. However, the majority of cells present in the vitreous samples of patients with PVR are capable of producing cytokines in vitro. Cultured RPE cells, upon activation, release IL-8, IL-6, and granulocyte-macrophage colony stimulating factor. ${ }^{15} 35$ Activated monocytes secrete a heterogeneous mixture of products that together strongly induce expression of many cytokines in human RPE cells. ${ }^{16}$ Most if not all of the inducing effect can be accounted for by IL- $1 \beta$ and $T N F \alpha$. Glial cells can produce IL-1. ${ }^{14}$ Macrophages and $\mathrm{T}$ lymphocytes can produce many different cytokines, including IL-1, IL-6, TNF $\alpha$, and IFN $\gamma .{ }^{36}$ In situ hybridisation technique combined with immunohistochemical staining for the vitreous samples or epiretinal membranes from patients with PVR might resolve which cell produce which cytokine.

The cells present in the vitreous at the time of sampling would determine the profile of the mRNA and cytokines detected. The number and type of cells present in the vitreous at different stages of the disease are likely to vary and consequently affect the types of cytokines expressed. ${ }^{36}$ This may in part explain why, in the present study, only a small number of samples revealed all the cytokines tested.

A novel observation in this current study concerns the cytokine IL-12. IL-12 mRNA was not detected in most of the samples investigated, being present in only two from 21 PVR, one from nine $\mathrm{RD}$, and not in any $\mathrm{MH}$ samples. However, IL-12 protein was detected in considerable amounts in examined samples (Table 3). A likely source of this IL-12 may be the iris, ciliary body, and choroid which normally contain dendritic cells. ${ }^{37}$ Activated dendritic cells are known to be a major source of IL-12. IL-12 is also produced by macrophages and B lymphocytes, which are known to infiltrate PVR membranes. It is also possible that this cytokine is primarily produced in the PVR membranes from where it accesses the vitreous gel. As PVR membranes were not analysed in this study, it not possible to comment on the correlation between IL-12 mRNA and the cytokine, in PVR membranes. IL-12 has multiple effects on $\mathrm{T}$ cells and natural killer (NK) cells. These include inducing production of IFN $\gamma$ and TNF either directly or in synergy with other inducers and acting as a co-mitogen to stimulate proliferation these cells. ${ }^{38} 39$ The involvement of activated $\mathrm{T}$ and $\mathrm{B}$ lymphocytes is well documented in the pathogenesis of the disease. $^{4041}$

The synergistic and pleiotropic effects of cytokines may be of particular importance in PVR. For example, IL-1 $\beta$ and TNF $\alpha$ both present within vitreous and epiretinal membranes, promote the synthesis of IL $-6,{ }^{42}$ and may also stimulate further IL-1 or $\mathrm{TNF} \alpha$ production. ${ }^{36}$ Moreover, IL-6 may induce further production of IL- 1 and TNF $\alpha .{ }^{43} \mathrm{IL}-1 \beta$ is known to enhance the contraction collagen gel $^{44}$ and may have a role PVR membrane contraction. In previous studies, IL-6 was detected at higher levels in PVR than in uncomplicated RD, although the same was not true for IL- $1 .{ }^{17}{ }^{19}$ In contrast, Kon et $a l^{24}$ found significantly elevated levels of IL- $1 \beta$ but not of IL-6 in patients with PVR compared with uncomplicated RD. We detected significantly elevated levels of both IL-6 mRNA and 
protein in patients with PVR versus $\mathrm{MH}$ and $\mathrm{RD}$. The same was true for IL- $1 \beta$ protein. IL- $1 \beta$ has been shown to enhance IL- 6 mRNA and protein synthesis in human RPE cells, and at lower concentrations, this effect was enhanced by TGF $\beta$ to induce IL- 8 mRNA but not IL-8 cytokine secretion..$^{45} \mathrm{~A}$ definitive role for IL-8 in the pathogenesis of PVR is not clear. However, it has been postulated that $\mathrm{TNF} \alpha$ and IL-1 $\beta$, which were not directly chemotactic for leucocytes, exert their chemotactic effect through induction and release of secondary cytokines including IL-8 and $\mathrm{MCP}-1 .^{20}$

IFN $\gamma$ is known to upregulate MHC class II molecule expression on RPE cells, and enhance presentation of foreign antigens to $T$ cells. ${ }^{46}$ Experimental studies show that epiretinal membrane formation can be accompanied by infiltration of blood borne lymphocytes and monocytes, which persist until the late stages of experimental PVR and are likely to be a source of IFN $\gamma .{ }^{47}$

In conclusion, our data indicate that levels of mRNA encoding IL-6, IL-8, IL-1 $\beta$, and IFN $\gamma$ is significantly increased in vitreous samples from patients with PVR, indicating local production of these cytokines by vitreous cells and the significant contribution of the invading cells in PVR pathogenesis. Cells invading the vitreous do not appear to locally produce IL-12, and apart from this cytokine there was a good correlation between mRNA and protein levels suggesting that mRNA measurements can provide useful information about cytokine synthesis within the invading cells. Monitoring of mRNA levels may aid in our understanding of this disease process and provide insights into progression, response to treatment, and development of strategies for alternative therapy.

The authors wish to acknowledge the help of Ms Sue Stevens for her excellent technical assistance. We also thank Mr Adrian Robins and Mr Richard McIntosh for help with the manuscript. Supported by a grant from the Uveitis Foundation, Wills Eye Hospital, Philadelphia, and the government of Egypt (IA El-Ghrably).

1 The Retina Society Terminology Committee. The classification of retinal detachment with proliferative vitreoretinopathy. Ophthalmology 1983;90:121-5.

2 Pastor JC. Proliferative vitreoretinopathy: an overview. Surv Ophthalmol 1998;43:3-18.

3 Wiedemann P, Weller $M$. The pathophysiology of proliferative vitreoretinopathy. Acta Ophthalmol 1988;189: (Suppl)7-15.

4 Glaser BM, Cardin A, Biscoe B. Proliferative vitreoretinopathy. The mechanism of development of vitreoretina traction. Ophthalmology 1987;94:327-32.

5 Charteris DG. Proliferative vitreoretinopathy: pathobiology, surgical management, and adjunctive treatment. $\mathrm{Br} \mathcal{F} \mathrm{Oph}$ thalmol 1995;79:953-60.

6 Campchiaro PA. Pathogenic mechanisms in proliferative vitreoretinopathy. Arch Ophthalmol 1997;115:237-41.

7 Cavaillon JM, Haeffner-Cavaillon N. Cytokines and inflammation. Rev Prat 1993;5:547-52.

8 Nagasaki H, Kouichi S. Risk factors for proliferative vitreoretinopathy. Curr Opin Ophthalmol 1995;6:70-5.

9 Roitt I, Brostoff J, Male D. Cell-mediated immune reactions. In: Immunology. 5th ed. London: Mosby, 1998; chapter 10:121-38.

10 Abbas AK, Lichtman AH, Pober JS. Cytokines in cellular and molecular immunology. 4th ed. Philadelphia: WB Saunders, 2000; chapter 11:235-69.

11 Camussi G, Albano E, Tetta C, et al. The molecular action of tumour necrosis factor- $\alpha$. Eur $f$ Biochem 1991;202:3-14.
12 Chaum E. Proliferative vitreoretinopathy. Int Ophthalmol Clin 1995;35:163-73.

13 Elner VM, BurnstineMA, Strieter RM, et al. Cell associated human retinal pigment epithelium interleukin-8 and monocyte chemotactic protein-1: immunochemical and in situ hybridisation analysis. Exp Eye Res 1997;65: 781-9.

14 Roberge FG, Caspi RR, Nussenblatt RB. Glial retinal Muller cells produce IL-1 activity and have a dual effect on autoimmune T helper lymphocytes. F Immunol 1988;140: 2193-6.

15 Planck SR, Huang X-N, Robertson JE, et al. Retinal pigment epithelial cells produces IL-1 $\beta$ and granulocytemacrophage colony stimulating factor in response to II- $1 \alpha$. Curr Eye Res 1993;12:205-12.

16 Jaffe GJ, Roberts WL, Wong HL, et al. Monocyte induced cytokine expression in cultured human retinal pigment epithelial cells. Exp Eye Res 1995;60:533-43.

17 Limb GA, Little BC, Meager A, et al. Cytokines in proliferative vitreoretinopathy. Eye 1991;5:686-93.

18 Limb GA, Alam A, Early O, et al. Distribution of cytokine proteins within epiretinal membranes in proliferative vitreproteins within epiretinal membranes in pro
oretinopathy. Curr Eye Res 1994;13:791-8.

19 Kauffmann DJ, Meurs JC, Mertens DA, et al. Cytokine in vitreous humor: interleukin-6 is elevated in proliferative vitreoretinopathy. Invest Ophthalmol Vis Sci 1994;35: 900-6.

20 Elner SG, Elner VM, Jaffe GJ, et al. Cytokines in proliferative diabetic retinopathy and proliferative vitreoretinopathy. Curr Eye Res 1995;1045-53.

21 Abu El-Asrar AM, Damme JV, Put W, et al. Monocyte chemotactic protein-1 in proliferative vitreoretinal disorchemotactic protein-1 in proliferative vitre
ders. Am f Ophthalmol 1997;123:599-606.

22 Aksunger A, Or M, Okur H, et al. Role of interleukin 8 in the pathogenesis of proliferative vitreoretinopathy. Ophthalmologica 1997;211:223-5.

23 Kenarova B, Voinov L, Apostolov C, et al. Levels of some cytokines in subretinal fluid in proliferative vitreoretinopathy and rhegmatogenous retinal detachment. Eur $\mathcal{7}$ Ophthalmol 1997;7:64-7.

24 Kon CH, Occleston NL, Aylward GW, et al. Expression of vitreous cytokines in proliferative vitreoretinopathy: a prospective study. Invest Ophthalmol Vis Sci 1999;40:70512 .

25 El-Ghrably IA, Dua HS, Orr GM, et al. Detection of cytokine mRNA production in infiltrating cells in proliferative vitreoretinopathy using reverse transcription polymerase chain reaction. $\mathrm{Br} \mathcal{F}$ Ophthalmol 1999;83: 1296-9.

26 Pannetier C, Delassus S, Darche S, et al. Quantitative titration of nucleic-acids by enzymatic amplification reactions run to saturation. Nucleic Acids Res 1993;21:577-83.

27 Dean GA, Higgins J, LaVoy A, et al. Measurement of feline cytokine gene expression by quantitative-competitive RTPCR. Vet Immunol Immunopathol 1998;63:73-82.

28 Ferre F, Marchese D, Pezzoli P, et al. Quantitative PCR. An overview. In: Mullis KB, Ferre F, Gibbs RA, eds. The polymerase chain reaction. Boston: Birkhauser, 1994:6788

29 Clementi M, Menzo S, Bagnarelli P, et al. Quantitative PCR and RT-PCR in virology. PCR Methods Appl 1993;3: 191-6.

30 Diviacco S, Norio P, Zentilin L, et al. A novel procedure for quantitative polymerase chain reaction by coamplification of competitive templates. Gene 1992;12:313-20.

31 Limb GA, Earley O, Jones SE, et al. Expression of mRNA coding for TNF $\alpha$, IL-1 $\beta$, and IL-6 by cells infiltrating reticoding for TNF $\alpha$, IL-1 $\beta$, and IL-6 by cells infiltrating reti232:646-52.

32 Kontakou M, Prezemioslo RT, Sturgess RP, et al. Expression of TNF $\alpha$, IL- 6 and IL-2 mRNA in the jejunum of patients with coeliac disease. Scand $\mathcal{F}$ Gastroenterol 1995;30:456-63.

33 Feldmann M, Brennan FM, Chantry D, et al. Cytokine production in the rheumatoid joint: implications for treatment. Ann Rheum Dis 1990;49:480-6.

34 Planck SR, Andresevic J, Chen JC, et al. Expression of growth factor mRNA in rabbit PVR model systems. 1992; 11:1031-9.

35 Elner VM, Strieter RM, Elner SG, et al. Neutrophil chemotactic factor (IL-8) gene expression by cytokine treated retinal pigment epithelial cells. Am F Pathol 1990;136:74550 .

36 Balkwill FR, Burke F. The cytokine network. Immunol Today 1989;10:299-303.

37 McMenamin PG. The distribution of immune cells in the uveal tract of the normal eye. Eye 1997;11:183-93.

38 D'Andrea A, Rengaraju M, Valiante NM, et al. Production of natural killer cell stimulatory factor (interleukin 12) by peripheral blood mononuclear cells. $\mathcal{F}$ Exp Med 1992;176: 1387-98.

39 Sutterwala FS, Mosser DM. The taming of IL-12: suppressing the production of proinflammatory cytokines. F Leukocyte Biol 1999;65:543-51.

40 Baudouin C, Fredj-Reygrobellet D, Gordon WC, et al. Immunohistochemical study of epiretinal membranes in proliferative vitreoretinopathy. Am f Ophthalmol 1990;110: 593-8.

41 Charteris DG, Hiscott P, Grierson I, et al. Proliferative vitreoretinopathy. Lymphocytes in epiretinal membranes. Ophthalmology 1992;99:1364-67. 
42 Akira $\mathrm{S}$, Hirano $\mathrm{T}$, Taga $\mathrm{T}$, et al. Biology of multifunctional cytokines: IL- 6 and related molecules (IL-1 and TNF $\alpha$ ). FASEB F 1990;4:2860-7.

43 Van Snick J. Interleukin-6. An overview. Annu Rev Immunol 1990;8:253-78.

44 Choudhury P, Chen W, Hunt RC. Production of plateletderived growth factor by interleukin- $1 \beta$ and transforming growth factor- $\beta$-stimulated retinal pigment epithelial cells leads to contraction of collagen gels. Invest Ophthalmol Vis Sci 1997;38:824-33.
45 Kuppner MC, Mckillop-Smith S, Forrester JV. TGF-beta and IL- 1 beta act in synergy to enhance IL-6 and IL-8 mRNA levels and IL-6 production by human retin pigment epithelial cells. Immunology 1995,84.265-71.

46 Jerdan JA, Pepose JS, Michels RG, et al. Proliferative vitreoretinopathy membranes. An immunocytochemical study. Ophthalmology 1989;96:801-10.

47 Hitchins CA, Grierson I. Intravitreal injection of fibroblasts: the pathological effects on ocular tissues of the rabbit following an intravitreal injection of autologous skin fibroblasts. Br f Ophthalmol 1988;72:498-510.

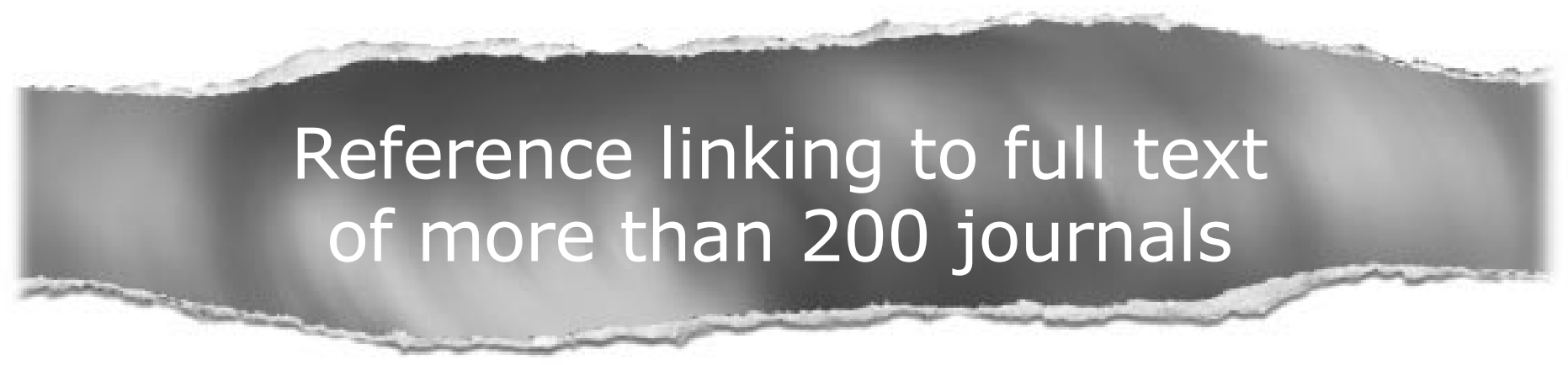

\section{Toll free links}

You can access the FULL TEXT of articles cited in the British Journal of Ophthalmology online if the citation is to one of the more than 200 journals hosted by HighWire (http://highwire.stanford.edu) without a subscription to that journal. There are also direct links from references to the Medline abstract for other titles.

www.bjophthalmol.com 